Nuno Ferreira and Susana Almeida, 'Portuguese report', in Aurelia Colombi Ciacchi, Chantal Mak and Zeeshan Mansoor (eds.), Immoral Contracts in Europe, Intersentia, 2020, available here: https://intersentia.com/en/immoral-contracts-in-europe.html

\title{
PORTUGUESE REPORT
}

\author{
Nuno Ferreira* \\ Susana Almeida ${ }^{\bullet}$
}

\section{Abbreviations}

Constitution of the Portuguese Republic (Constituição da República Portuguesa, CRP)

Medically Assisted Procreation Act (Procriação medicamente assistida, MAP Act)

Portuguese Civil Code (Código Civil, CC)

Portuguese Labour Code (Código do Trabalho, CT)

Portuguese Penal Code (Código Penal, CP)

N.B. Constitutional Court (Tribunal Constitucional) decisions are available on http://www.tribunalconstitucional.pt. Most decisions from all other courts are available on http://www.dgsi.pt.

* Professor of law, University of Sussex, UK.

- Associate Professor, School of Technology and Management, Polytechnic Institute of Leiria, Portugal; IJP/Leiria Researcher. 


\section{CASE 1}

\section{Operative Rules}

Miss Butterfly would most likely not have a claim against Mr Bighead.

\section{Descriptive Formants}

Prostitution does not constitute a crime under the current Portuguese Penal Code (Código Penal, CP), since the 1982 penal code reform. ${ }^{1}$ Yet, even if not constituting a crime, prostitution can still be considered 'immoral', as expressly asserted in a 1985 Supreme Court decision ${ }^{2}$ and 1992 Constitutional Court decision. ${ }^{3}$ Although other judicial decisions seem more lenient and approach prostitution from a morally neutral stance, ${ }^{4}$ scholarly works also reinforce the idea that prostitution is still 'immoral' by stating that not punishing prostitution criminally does not equate to a right to prostitute oneself. Public policy and good morals may still limit a prostitute's activity, namely within the confines of brothels. ${ }^{5}$

Moral values pervade private law and their privileged entrance point into Portuguese law is Article 280(2) CC, which states:

'A legal transaction contrary to public policy or offensive of good morals is null.'

\footnotetext{
1 Decreto-Lei n. ${ }^{\circ}$ 400/82, 23 September 1982. Nevertheless, 'pandering' ('lenocínio', in Portuguese legal terminology) remains a crime, as foreseen in Article $169 \mathrm{CP}$.

${ }^{2}$ Decision quoted in Susana Silva, 'Classificar e silenciar: Vigilância e controlo institucionais sobre a prostituição feminina em Portugal’ (2007) XLII Análise Social 184, 799.

${ }^{3}$ Tribunal Constitucional, Acórdão n. ${ }^{\circ}$ 128/92 (1 April 1992), with regard to a rented property where prostitution related activities took place. See, also, official document issued by the Immigration and Borders Service, asserting that working in bars to accompany clients and convince them to drink more ('alterne') corresponds to an immoral activity in violation of Article 280(2) CC: Informação n260/GJ/05, Gabinete Jurídico do SEF, cited Tribunal da Relação do Porto (Court of Appeal of Porto), Process n. ${ }^{\circ}$ 94/10, 13 June 2012.

${ }^{4}$ Tribunal da Relação do Porto (Court of Appeal of Porto), 11 July 1991 (decision not published), with regard to prostitution-related activities in a rented space used as a cinema.

5 Luísa Neto, O Direito Fundamental à Disposição Sobre o Próprio Corpo (A Relevância da Vontade na Configuração do Seu Regime) (Coimbra: Coimbra Editora, 2004) 658, which discusses Constitutional Court decisions determining the unconstitutionality of regional norms prohibiting prostitution activities by the road (Tribunal Constitucional, Acórdãos n. ${ }^{\circ}$ 185/96 (27 February 1996) and n. ${ }^{\circ} 83 / 01$ (25 March 2001). However, the grounds for this finding lie in the fact that such norms could only be approved by the national legislature and not regional authorities, considering they curtail fundamental freedoms. Such norms could, therefore, be potentially valid if they are approved by the national legislature.
} 
Moral values are thus considered yardsticks in the assessment of the validity of legal transactions (both contracts - as legal transactions involving at least two parties - and unilateral legal transactions - as legal transactions involving only one party). The two key notions used in this norm are 'public policy' and 'good morals' (literally, in Portuguese, 'good customs', corresponding to the Latin 'boni mores'). 'Public policy' and 'good morals' are 'indeterminate concepts' (general clauses), whose precise scope and reach is to be rendered specific by decision-makers based on the facts of each case. ${ }^{6}$

Furthermore, a legal transaction may in itself be lawful (to the extent that is in accordance with the law, public policy and good morals), but still be void because the parties involved use the legal transaction in question to pursue aims incompatible with public policy or good morals. Almeida Costa offers the example of an individual who sells a gun to another individual (legal transaction in itself legal, as long as compliant with the licensing requirements established statutorily), knowing that the gun will be used to murder a third individual (aim incompatible with public policy and good morals). ${ }^{7}$ In such cases, nullity only strikes a legal transaction when the 'subjective aim' of all parties to the transaction is contrary to public policy or good morals (Article 281 CC). In other words, all parties involved must have the common aim of violating public policy or good morals.

A particular case of application of the notions of good morals and public policy to prostitution pertains to tenancy contracts: Article 1083(2)(b) CC determines that the use of the property in violation of good morals or public policy may, considering its seriousness or consequences, justify the termination of the contract. This provision needs to be interpreted in a way that is compatible with the values of a democratic, pluralistic and open society, as enshrined in the Constitution. ${ }^{8}$ Still, the Constitutional Court has considered this norm constitutional, namely compatible with the rights to personal integrity and identity, honour, image and privacy (Articles 25 and $26 \mathrm{CRP}$ ), bearing in mind that the tenant accepts limitations to these rights

\footnotetext{
${ }^{6}$ António Menezes Cordeiro, Tratado de Direito Civil Português, vol. I (Coimbra: Almedina, 2000) 498; Luís Manuel Teles de Menezes Leitão, Direito das Obrigações, vol. I (Coimbra: Almedina, 2010) 120-121; Mário Júlio de Almeida Costa, Direito das Obrigações, 7th edition revised and updated (Coimbra: Almedina, 1998) 621; Neto (n 5) 475-77.

${ }^{7}$ Almeida Costa (n 6) 621.

${ }^{8}$ Tribunal Constitucional, Acórdão n. ${ }^{\circ}$ 128/92 (1 April 1992).
} 
when entering into a tenancy contract - the possibility of using the property for the purposes of prostitution being consequently excluded. ${ }^{9}$

Despite the lack of detail in scholarly studies, some authors use precisely a contract having 'sexual favours' as its object as an example of nullity on grounds of violation of good morals, as enshrined in Article 280(2) CC. ${ }^{10}$ It is doubtful, however, whether this is a defensible position in light of the evolution of sexual mores in Portuguese society. This is a clear example of a conflict between the 'public policy' values and the individual morals (as opposed to the 'good morals').

At any rate, even if the contract is held null, Miss Butterfly may theoretically invoke unjust enrichment (prohibited by Article $473 \mathrm{CC}$ ). Considering the legal framework delineated above, however, a decision-maker would probably be inclined to consider it immoral to put a price on the 'enrichment' or benefit obtained by Mr Bighead, and would therefore deny Miss Butterfly any compensation. The outcome would probably be the same should Miss Butterfly claim for compensation for a violation to her physical integrity and personality rights, as Miss Butterfly consented to having sexual intercourse (even if this was based on the assumption that she would be paid for it).

\section{Meta-legal Formants}

Prostitution remains a contentious issue in Portuguese society. Despite being tolerated for the most part and there being numerous prostitution advertisements in the newspapers, prostitutes possess very low social esteem, and are either non-entities or connected to criminal activities. Some Portuguese authors have argued for the adoption of the Swedish model, which prohibits prostitution but, instead of punishing the prostitute, criminalises the client's conduct and the exploitation and trafficking of prostitutes. ${ }^{11}$ In 2006, the presidential candidate Mário Soares also expressed his opinion in favour of the legalisation of prostitution, but none of the other presidential candidates shared this approach. ${ }^{12}$ Recently, a motion approved by the Socialist

\footnotetext{
${ }^{9}$ Ibid.

${ }^{10}$ Menezes Cordeiro (n 6) 500; Menezes Leitão (n 6) 121.

${ }^{11}$ Pedro Maria Godinho Vaz Patto, 'O tratamento jurídico da prostituição' (2008) 167 Brotéria 215-241.

${ }^{12}$ LUSA, 'Cavaco Silva e Jerónimo de Sousa assumem posições opostas sobre privatizações', 13 December 2005 , $<$ http://www.publico.pt/politica/noticia/cavaco-silva-e-jeronimo-de-sousa-assumem-posicoes-opostas-sobreprivatizacoes-1241835> accessed 5 October 2018.
} 
Party in the Party's National Council brought up the subject once again, but the regulation of prostitution is still just a debate in the Portuguese society. ${ }^{13}$

\section{CASE 2}

\section{Operative Rules}

Mr Pioneer would most likely have a claim against Miss Pearl.

VARIATION: Mr Pioneer would probably not have a claim against Miss Pearl.

\section{Descriptive Formants}

One could argue that by leasing a limousine to Miss Pearl and knowingly allowing her to carry out her prostitution activity in the limousine, Mr Pioneer is effectively facilitating, with a profitmaking intention, Miss Pearl's professional activity. If that were the case, Mr Pioneer would, in practice, be committing a crime, as 'pandering' ('lenocínio', in Portuguese legal terminology) is defined by Article 169(1) CP as professionally or intentionally favouring or facilitating the prostitution of someone else. Such conduct is criminally punishable with imprisonment between six months and five years.

'Pandering' ('lenocinio') has been the object of several Portuguese Constitutional Court decisions, which have consistently asserted the constitutionality of the criminalisation of 'pandering'. ${ }^{14}$ The arguments generally adduced in favour of the constitutionality of the Penal Code norm relate to the protection of the autonomy and dignity of persons who prostitute themselves, in the sense that the norm prevents the danger of the autonomy of people who prostitute themselves being reduced through the action of third parties acting professionally or for profit. The fact that prostitution itself is not a crime is irrelevant for these purposes, as exploiting one's own body for sexual purposes and another person's body for those purposes are considered conducts with different legal relevance. In two decisions of the Portuguese

\footnotetext{
${ }^{13}$ Liliana Valente, 'JS quer regulamentar prostituição, mas para já a preocupação é debater o tema', 11 March 2017, <https://www.publico.pt/2017/03/11/sociedade/noticia/js-quer-regulamentar-prostituicao-mas-para-ja-soa-debate-1764781> accessed 5 October 2018.

${ }^{14}$ Tribunal Constitucional, Acórdãos n. ${ }^{\circ} 114 / 04$ (10 March 2004), 196/04 (23 March 2004), $303 / 04$ (5 May 2004), 170/06 (6 March 2006), 396/07 (10 July 2007), 654/2011 (21 December 2011), 641/2016 (21 November 2016), 421/2017 (13 July 2017), and 694/2017 (18 October 2017).
} 
highest courts, however, votes of dissent have argued in favour of the unconstitutionality of the criminalisation of 'pandering', highlighting: (i) the need to only make penal law intervene as a last resort, (ii) the fact that the prostitute's sexual freedom does not require such penal intervention, and (iii) that the penal code norm may only punish conducts involving exploitation and not those where prostitutes have freely chosen their activity. ${ }^{15}$ Moreover, in a 2017 judgment, the Court of Appeal of Porto (Tribunal da Relação do Porto) declared the unconstitutionality of the criminal punishment of 'pandering', based on the lack of specific legally protected object, and submitted that this conduct should be punished in the future as a mere administrative offence ('contraordenação'). ${ }^{16}$ This trend to decriminalise 'pandering' is also clear in recent judgments of the Constitutional Court, where the dissenting votes and weak majorities seem to foresee a different approach to 'pandering' in the near future. ${ }^{17}$ Scholars have also sporadically supported this view, arguing in favour of the legalisation and regulation of the 'pandering' activity, in the light of the right to freedom and damage reduction. ${ }^{18}$ For the time being, however, Article $169 \mathrm{CP}$ - criminalising 'pandering' - remains in force.

If we consider that a crime of 'pandering' has taken place, a contract that supports such conduct would be considered against public policy and good morals, thus null according to Article 280(2) CC. However, in this case Mr Pioneer could try to file a claim for unjust enrichment (Article $473 \mathrm{CC}$ ), to the extent that Miss Pearl has enjoyed the limousine for a month without paying for it. Still, the probability of success of this claim would be doubtful, as a decisionmaker could invoke the immoral character of prostitution and Mr Pioneer's knowledge of Miss Pearl's activities in the limousine to assert as well that the unjust enrichment claim is immoral and against public policy.

Nonetheless, one can also argue that, in the case in question, Mr Pioneer may have merely acted with 'indirect intention' ('dolo indireto') or 'wilful ignorance' ('dolo eventual') since he found out about Miss Pearl's professional activity and her use of the limousine. That would be

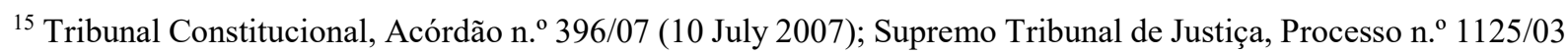
(5 September 2007).

${ }^{16}$ Tribunal da Relação do Porto (Court of Appeal of Porto), Processo n. ${ }^{\circ}$ 404/13.9TAFLG.P1 (8 February 2017).

${ }^{17}$ Tribunal Constitucional, Acórdãos n. ${ }^{\circ}$ 641/2016 (21 November 2016), 694/2017 (18 October 2017). In Acórdão n. ${ }^{\circ}$ 641/2016, the President of the Portuguese Constitutional Court, Manuel da Costa Andrade, in his dissenting vote, sustained that 'leaving out sexual freedom from the scope of protection of the norm [Article $169 \mathrm{CP}$ ] means that only preventing or repressing a sin is in question, which is a retrograde moralistic exercise with which criminal law in a rule of law system of the current secularised and democratic society should not be involved.'

${ }^{18}$ For a review of the relevant decisions and scholarly works, see Vaz Patto (n 11) 216-220.
} 
insufficient to apply Article $169 \mathrm{CP}$ to this case, as that would excessively stretch the objective scope of this norm. ${ }^{19}$ To apply this norm, Mr Pioneer would have had to act with 'direct intention' ('dolo direto'), i.e., he would have had to intend to profit not only from leasing the limousine, but also - and specifically - from Miss Pearl's prostitution activity. That does not seem to be the case on the facts described. ${ }^{20}$

Assuming there has not been a crime of 'pandering', the facts should be simply analysed from the perspective of civil law and Articles $762 \mathrm{ff} \mathrm{CC}$ on contractual fulfilment. Mr Pioneer could thus enforce the contract.

VARIATION: This scenario seems to worsen the conduct of Mr Pioneer, as he seems to intend to profit not only from leasing the limousine, but also from Miss Pearl's activity. This could ascertain 'direct intention' ('dolo direto') and, therefore, the commission of a crime of 'pandering'. If that were the case, the legal transaction with Miss Pearl could be immoral and null according to Article 280(2) CC. Alternatively, the contract between Mr Pioneer and Miss Pearl can be considered voidable due to usury, under Article $282 \mathrm{CC}$, if it is ascertained that $\mathrm{Mr}$ Pioneer exploited Miss Pearl's state of necessity, inexperience or dependency to obtain for himself excessive or unjustified benefits.

\section{Meta-legal Formants}

Similar to the activity of prostitution, 'pandering' is socially reproached but mostly tolerated, especially in the shape of night venues explored for those purposes ('bares de alterne'). There are numerous advertisements on newspapers that involve 'pandering' to some extent, which again are for the most part socially tolerated and rarely prompt any police or judicial activity. In the light of recent case law discussed above and increasing social tolerance of prostitution and 'pandering', it is foreseeable that 'pandering' will be decriminalised in the near future.

\footnotetext{
${ }^{19}$ This has been the opinion also expressed by two judges consulted informally during the preparation of this report.

${ }^{20}$ Also suggesting that the facts in question do not constitute a crime of 'pandering' (although in reference to a tenancy contract), see Anabela Miranda Rodrigues, 'Art. 170.', Comentário Conimbricense do Código Penal (Coimbra: Coimbra Editora, 1999), 525-526.
} 


\section{CASE 3}

\section{Operative Rules}

WICKED can most likely set-off FUN's claim and present a counter-claim.

\section{Descriptive Formants}

Loan agreements are regulated in Articles $1142 \mathrm{ff} \mathrm{CC}$ and the possibility of set-off in Articles $847 \mathrm{ff} \mathrm{CC}$.

The case concerns an activity that, whilst not being a mainstream and orthodox business activity, falls short of being prostitution and, arguably, would not be object of the same moral judgment as prostitution is. Indeed, telephone sex does not have the same social stigma or the same impact on an individual's physical and moral integrity. Furthermore, such services are known to exist in Portugal and their legality has, to the authors' knowledge, never been questioned, neither in the media nor in the courts. It is thus likely that a judge would consider this activity compatible with public policy and good morals. This conclusion can be further reinforced by invoking Article $37 \mathrm{CRP}$, on the right to freedom of expression, and Article 61 $\mathrm{CRP}$, which protects the right to private economic enterprise as a particular dimension of the right to private autonomy.

That being the case, the marketing and loan contracts are legal, and, upon the breaking down of the business relationship, WICKED is entitled to set-off the amounts in debt.

\section{CASE 4}

\section{Operative Rules}

Mr Courage would most likely have a claim.

VARIATION: The bar can most likely recover the money, but not require specific performance. 


\section{Descriptive Formants}

The rights of workers are extensively protected at constitutional and ordinary (civil and labour) level. At the constitutional level, such rights may be subject to restrictions, but 'such restrictions must be limited to those needed to safeguard other constitutionally protected rights and interests' (Article 18(2) CRP), subject to the principle of proportionality. ${ }^{21}$ Individual employment agreements may include clauses consenting to the limitation of fundamental rights, provided such consent is truly free and informed; such clauses may not, however, fully renounce fundamental rights. ${ }^{22}$

At an ordinary level, workers' personality rights are also protected by the current Labour Code (Código do Trabalho, CT) ${ }^{23}$, namely Articles $14 \mathrm{ff}$, as well as Articles $70 \mathrm{ff} \mathrm{CC}$. The law allows for the voluntary limitation of one's personality rights, but such limitation is held to be null when deemed contrary to public policy (Article 81(1) CC). Most importantly, any voluntary limitation is freely revocable (unilaterally and at any time), even if that may entail the obligation to compensate any affected parties (Article $81(2) \mathrm{CC}){ }^{24}$ The possibility of specific performance or pecuniary sanctions would be offensive of one's fundamental personal rights. ${ }^{25}$

It is submitted that Mr Courage's situation can be described as a legitimate self-limitation of fundamental and personality rights, as it is not prohibited by any particular constitutional, civil or labour specific norm. The right to dignity, as generally formulated in the Constitution, does not seem to suffice to prohibit such self-limitation; in fact, $\mathrm{Mr}$ Courage's right to free development of personality may impose the legality of the agreement in question. Also, the activity in question is arguably compatible with public policy and good morals, to the extent that one uses one's body in all sorts of ways in different professional activities without attracting a legal prohibition (for example, strip-tease, modelling, pugilism, certain forms of artistic expression, etc.), even when such activity may seem degrading to a particular person.

\footnotetext{
${ }^{21}$ José João Abrantes, 'Labour contract and fundamental rights' (2004) 80 Boletim da Faculdade de Direito 613630 at 630.

${ }^{22}$ Raquel Tavares dos Reis, Liberdade de consciência e de religião e contrato de trabalho do trabalhador de tendência: Que equilibrio do ponto de vista das relações individuais de trabalho? (Coimbra: Coimbra Editora, 2004) 73; Abrantes (n 21) 629.

${ }^{23}$ Approved by Lei n. ${ }^{\circ}$ 7/2009, 12 February 2009.

${ }^{24}$ Carlos Alberto da Mota Pinto, Teoria Geral do Direito Civil (Coimbra: Coimbra Editora, 2005), 207-220.

${ }^{25}$ Tavares dos Reis (n 22) 75.
} 
VARIATION: Any self-limitation of fundamental and personality rights is revocable at any time, so Mr Courage may refuse to perform the agreement. Nonetheless, he will be liable to compensate the bar for any damage that it may suffer as a consequence, including any payment made to him (Article 81(2) CC). The bar will not, however, be able to request specific performance, as that would translate into an imposition of limitation of fundamental and personality rights without the consent of the person concerned, in violation of Articles $70 \mathrm{CC}$ and 25-26 CRP.

\section{Meta-legal Formants}

There has been a case of 'dwarf throwing' in a dance club in Vila do Conde, a town in northern Portugal. To the authors' knowledge, the case was not dealt with by courts, but it did catch scholars' attention. ${ }^{26}$ More recently, the press also took note of a business of 'dwarf throwing' being launched in Portugal. ${ }^{27}$

One can argue - at least from a de jure constituendo perspective - that a dwarf has as much right to consent to being thrown as prostitutes have the right to make their body sexually available to a client - neither activity should, therefore, be legally prohibited. Nonetheless, and equally similarly to a prostitute, there is no obligation to remain bound to contractual duties involving such an interference with one's body, so both prostitutes and dwarfs have the right to terminate any contractual obligation involving their bodies. Hence, there should not be a violation of the prostitute's or the dwarf's dignity for as long as their consent subsists, but once that consent is withdrawn, any insistence on binding the prostitute or dwarf to their initial contractual obligations becomes a violation of their dignity.

\footnotetext{
${ }^{26}$ Discussed in José Carlos Vieira de Andrade, Os direitos fundamentais na Constituição Portuguesa de 1976, 4th edition (Coimbra: Almedina, 2009) 311, note 113.

27 Márcia Galrão, 'Quem quer lançar um anão?', Visão, 13 June 2016, $<$ http://visao.sapo.pt/actualidade/sociedade/2016-06-13-Quem-quer-lancar-um-anao-> accessed 5 October 2018.
} 


\section{CASE 5}

\section{Operative Rules}

The couple may not require Miss Swan to give Donny to them.

The couple may reclaim the amount of money they paid Miss Swan, although not all of it may have to be repaid.

VARIATION 1: At a criminal level, yes, but not at a civil level (the only difference would be the amount of money that would need to be repaid).

VARIATION 2: It would not have made any difference.

\section{Descriptive Formants}

The Medically Assisted Procreation (MAP) $\mathrm{Act}^{28}$ was amended by Act No. 25/2016, 22 August 2016, which legalised in Portuguese law gratuitous (not-for-profit) surrogacy, on an 'exceptional basis' and upon fulfilment of several positive and negative conditions. Until this amendment, surrogacy was prohibited under any circumstance. The 2016 amended version of Article 8(1) MAP Act defined surrogacy as any situation where a woman is willing to carry out a pregnancy on behalf of another and to hand over the child after the birth, renouncing the powers and duties typically associated with maternity. Article 8(2) MAP Act allowed the entering into altruistic surrogacy contracts on an exceptional basis, 'in the case of absence of uterus, damage to or illness in this organ that completely and permanently prevents the woman's pregnancy or in clinical contexts that justify so', and Article 8(4) requires an authorisation of the National Council of MAP. ${ }^{29}$ Article 8(3) MAP Act stated that surrogacy could only be authorised when gametes of at least one of the beneficiaries were used and under no circumstance could the surrogate mother be a donor of an oocyte in a procedure in which she were taking part. Article 8(5) MAP Act prohibited any payment or donation to the surrogate mother, except compensation for expenses, duly proven, related to the health care provided.

\footnotetext{
${ }^{28}$ Lei n. $^{\text {o } 32 / 2006,} 26$ July 2006, Procriação medicamente assistida.

${ }^{29}$ Decreto Regulamentar n. $^{\circ}$ 6/2017, 31 July 2017, regulated Act No. 25/2016 (Lei n. ${ }^{\circ}$ 25/2016) and, in the light of its Article 3, the National Council of MAP (Conselho Nacional de Procriação Medicamente Assistida) approved a surrogacy standard contract, available online: $<$ http://www.cnpma.org.pt/Docs/ContratoTipo_GS.pdf $>$ accessed 5 October 2018.
} 
Finally, Article 8(8) MAP Act, combined with Article 14(5), established that the surrogate mother could only revoke consent until the beginning of MAP therapeutic procedures.

Following some academic commentators, ${ }^{30}$ in a 2018 judgment the Constitutional Court has severely criticised the lack of detail of the legal regulation of the surrogacy contract. ${ }^{31}$ The Court argued that: (i) the legislature had not foreseen the positive and negative limits to the autonomy of the parties in designing the contract; and (ii) the law omitted the criteria for 'previous authorisation' and monitoring of the content of the contract. On these grounds, the Court declared as generally (as opposed to specifically in a certain situation) unconstitutional the norms that allowed entering into surrogacy agreements on an 'exceptional basis' and upon 'previous authorisation', for violating the principle of determinability of the law. The Court also asserted that limiting the free revocability of consent by the surrogacy mother was unconstitutional for disproportionally restricting the right to free development of one's personality, interpreted in the light of the principle of human dignity. The Court thus declared unconstitutional Article 8(2), (3), (4), (10) and (11), as well as Article 8(8) combined with 14(5) MAP Act as amended by the 2016 Act. $^{32}$

Bearing all this in mind, one can conclude that surrogacy is legally enshrined in the Portuguese law, but the legislature needs to approve further norms that will regulate surrogacy in terms that are compatible with the constitutional parameters. Following the Constitutional Court's declaration of unconstitutionality of the 2016 amendments, the previous legal framework became applicable (Article 282(1) CRP) and surrogacy again became prohibited under any circumstance.

In the light of the facts of the case, and even if the Constitutional Court had not declared as unconstitutional the 2016 amendments, the surrogacy contract entered into by Miss Swan and Mr and Mrs Duck would be illegal, and thus null (Article 8(12) MAP Act), as the surrogate mother cannot under any circumstance donate an oocyte to create an embryo in a process of which she is part.

\footnotetext{
${ }^{30}$ Vera Lúcia Raposo, 'Tudo aquilo que você sempre quis saber sobre contratos de gestação (mas o legislador teve medo de responder)' (2017) 149 Revista do Ministério Público 9-51 at 23-24.

${ }^{31}$ Acórdão n. ${ }^{\circ} 225 / 2018,24$ April 2018.

${ }^{32}$ To safeguard legal certainty, however, the Court limited the effects of this declaration of unconstitutionality to those contracts effectively entered into according to the 2016 Act.
} 
At a civil level, by committing to relinquish a baby that one has gestated, one is also committing to relinquish a personal right. Even if that commitment were not considered null for violating the good morals clause (Article $280 \mathrm{CC}$ ), it is a commitment that is revocable, even if upon compensation for the damage caused to the other party (Article 81(2) CC). ${ }^{33}$ Nonetheless, the 2006 law (currently valid, as described above), along with several Portuguese authors, considers that surrogacy contracts are against good morals, even when not entailing a pecuniary compensation, so they violate Article 280 CC. Should such a contract be carried out anyway, all parties are obliged to return all that they have received (Article $289 \mathrm{CC}$ ), except compensation for expenses incurred and damage suffered - generally by the surrogate mother - provided that the requisites of pre-contractual liability are fulfilled (Article $227 \mathrm{CC}$ ) and such obligation to compensate is not excluded by the fault of the one who is to be compensated (Article $570 \mathrm{CC}){ }^{34}$

At a criminal level, Article 39 (1) and (2) MAP Act criminalises surrogacy upon payment and punishes the parties to such surrogacy contracts with imprisonment up to two years or a fine up to 240 days (in the case of beneficiaries) or simply a fine up to 240 days (in the case of the surrogate mother). ${ }^{35}$ Moreover, Article 39(3) MAP Act establishes that parties to gratuitous surrogacy contracts outside the limits legally prescribed (in Article 8) can be imprisoned up to one year or liable to pay a fine up to 120 days (in the case of beneficiaries) or simply liable to pay a fine up to 120 days (in the case of the surrogate mother). These norms may, however, be also deemed (consequentially) unconstitutional in the sequence of the Constitutional Court's 2018 judgment. If the Constitutional Court had not declared the unconstitutionality of the 2016 version of Article 8(3) MAP Act, the contract in question in this case would be unlawful owing to the use of Miss Swan's oocyte, and Mr and Mrs Duck could be imprisoned up to one year or liable to pay a fine up to 120 days and Miss Swan would be liable to pay a fine up to 120 days.

\footnotetext{
${ }^{33}$ Furthermore, based on an analogy with the rules applicable to adoption, one could argue that birth mothers should only be allowed to relinquish their baby six weeks after the child's birth (Articles 1882 and 1982 CC). This argument may be criticised on grounds of being built on the assumption that the birth mother has offered her genetic material to the baby, which may not be the case in surrogacy: Tiago Duarte, In vitro veritas? A procriação medicamente assistida na Constituição e na lei (Coimbra: Almedina, 2003) 87-8; Jorge Duarte Pinheiro, 'Mãe portadora: A problemática da maternidade de substituição', in José de Oliveira Ascensão (ed), Estudos de direito da bioética (vol 2, Coimbra: Coimbra Editora, 2008) 323-344, at 336.

${ }^{34}$ Duarte Pinheiro (n 33) 336-7.

35 According to Article $47 \mathrm{CP}$, fines may be set between 10 and 360 days, and the value of each day may be set between EUR 5 and EUR 500, depending on the personal economic situation of the defendant and their financial obligations. This means that a fine of up to 240 days may translate into a figure between EUR 50 and EUR 120,000.
} 
With the 2018 declaration of unconstitutionality, the original (2006) legal regime became applicable again, and gratuitous surrogacy is again not criminally punishable.

In the scenario presented, it is thus clear that the couple would not be able to require Miss Swan to give Donny to them: the agreement is null and Miss Swan is the legal mother of Donny, as laid down in Article 1796 of the CC. Still, the couple may reclaim the amount of money they paid Miss Swan, although not all of it may have to be repaid if Miss Swan incurred expenses or suffered any damage due to the pregnancy, has acted in good faith during the negotiations leading to the surrogacy contract, and has not acted with fault with regard to any damage suffered.

VARIATION 1: At a criminal level, this scenario (contrarily to the previous one) would entail the conviction of Mr and Mrs Duck and Miss Swan, and imprisonment for up to two years or a fine up to 240 days, as laid down in the 2006 original version of Article 39(1) MAP Act. At a civil level, it would entail the repayment by Miss Swan of the EUR 25,000.

VARIATION 2: In the light of the declaration of unconstitutionality of Article 8(3) MAP Act and the current validity of the 2006 original legal regime, the origin of the genetic material is immaterial for these purposes, as the surrogacy agreement is still held illegal and the surrogate mother is still held as the legal mother.

\section{Meta-legal Formants}

Portuguese authors have attempted to conceptualise surrogacy contracts as one of the type of contracts foreseen in the civil code. The most common opinion seems to be that surrogacy contracts are atypical service contracts (Article $1154 \mathrm{CC}$ ), to the extent that one party commits to offering the results of their work to another party. ${ }^{36}$

For some, such surrogacy contracts should be held contrary to good morals, as they entail collection of genetic material through means that go against human dignity and morality. ${ }^{37}$ However, others highlight that allowing surrogacy may actually be a constitutional requirement

\footnotetext{
${ }^{36}$ Duarte Pinheiro (n 33) 330.

${ }^{37}$ Discussed in Neto (n 5) 599, with reference to the work of Spanish authors.
} 
of the right to life (Article $24 \mathrm{CRP}$ ), principle of equality (Article $13 \mathrm{CRP}$ ), the right to constitute a family (Article $36 \mathrm{CRP}$ ), and the right to private autonomy (Articles 26 and $27 \mathrm{CRP}$ ), primarily on two accounts: (i) if the law allows for methods to overcome male infertility (heterologous insemination, i.e., sperm donation), then it should also allow for methods to overcome female infertility; ${ }^{38}$ (ii) if the law allows for mothers without egg cells to become pregnant, then it should also allow those women with egg cells but unable to carry an embryo and/or foetus to have children. ${ }^{39}$ Yet, creating human life and the right to procreate are not absolute rights, as they must also be the result of a conscious and sensible process that holds the child's interests and protection (Article $69 \mathrm{CRP}$ ) as the most important. ${ }^{40}$ In addition, the rights to private autonomy and contractual freedom are limited by fundamental rights, which explains why legal transactions may be held null for violating good morals or public policy (Article $280 \mathrm{CC})$.

The key ethical issue is, in fact, whether surrogacy is paid for or not. Should there be pecuniary compensation for surrogacy (beyond the costs involved with carrying and delivering the baby), then one would be putting a price on a child, commodifying children, and consequently violating the right to dignity of the human person (Article 1 CRP) and the good morals clause (Article $280 \mathrm{CC}$ ). Should there not be any pecuniary compensation, courts could decide on a case-by-case basis and considering public family policy which solution would satisfy the best interests of the child, or the law could allow such contracts under tight conditions (for example, the surrogate mother not being the genetic mother as well) and to be carried out in specialised centres (perhaps supported by legal adoption mechanisms). ${ }^{41}$ Overall, some authors seem to favour the position of the surrogate mother on the basis of the 'organic link', others seem to empathise more with the biological mother (when the biological mother is not the surrogate mother) based on the overall primacy still afforded by Portuguese law to biological links when determining filiation. ${ }^{42}$ Doctors also seem to be open to the lawfulness of surrogacy, as Article

\footnotetext{
${ }^{38}$ Ibid 599.

${ }^{39}$ Duarte (n 33) 87.

${ }^{40}$ Duarte Pinheiro (n 33) 333; Francisco Pereira Coelho and Guilherme de Oliveira, Curso de Direito da Família, vol. 1, 5th edition (Coimbra: Imprensa da Universidade de Coimbra, 2016) 156.

${ }^{41}$ Neto (n 5) 599, discussing arguments expounded by Guilherme de Oliveira; Duarte (n 33 ) 87 ff; Carlos Pamplona Corte-Real and José Silva Pereira, Direito da Família: Tópicos para uma reflexão crítica (Lisboa: AAFDL, 2008) 144.

${ }^{42}$ This is the case, for example, of José de Oliveira Ascensão, Procriação assistida e direito, in Estudos em homenagem ao Professor Doutor Pedro Soares Martinez, vol. 1 (Coimbra: Almedina, 1998) 668; and Duarte (n 33) 87.
} 
63(5) of the Medical Association Professional Code (Código Deontológico da Ordem dos Médicos) has accepted surrogacy in exceptional cases since $2009 .{ }^{43}$

\section{CASE 6}

\section{Operative Rules}

The contract is partially valid, and Mr Lonely may not recover the deposit (at least not all of it). VARIATION: The contracts are partially valid, and Mr and Mrs Settled can challenge the agency's claim.

\section{Descriptive Formants}

As explored in greater detail in Case 8 below, 'celibacy clauses' are null for being against public policy, in particular the fundamental right to form a family and marry (Article $36 \mathrm{CRP}) .{ }^{44} \mathrm{By}$ analogy, one may consider that any interference with one's freedom to marry or not to marry is against public policy.

The contract in question in this scenario entails a provision of service that may itself be considered legal and compatible with good morals and public policy, as the agency simply uses its structure to put the client in touch with other people. It is thus considered legitimate to be paid for such service. However, making part of the cost (and payment) for the service dependent on the client marrying is a condition precedent that should be held against good morals and public policy for exerting influence on the client in relation to his fundamental right to marry. Indeed, potentially the client could choose not to marry, simply for the sake of not paying the remaining EUR 2,000, which would indicate the negative impact that the brokerage contract can have on the exercise of one's fundamental right to marry.

As the condition precedent in question is contrary to good morals and public policy, it renders the contract null, as established by Article $271 \mathrm{CC}$. One can, however, argue that the nullity only affects the contractual clause regarding the payment upon marriage, and not the clause

\footnotetext{
${ }^{43}$ Regulamento n. ${ }^{\circ}$ 14/2009, 13 January 2009.

${ }^{44}$ Mota Pinto (n 24) 76.
} 
pertaining to the payment of the deposit for the services of Forever Happy Marriage Bureau. This would constitute a 'reduction' of the initial contract, under Article 292 CC. Alternatively, one can also hypothesise that the original contract could be 'converted' into a contract of smaller scope, only relating to the services of Forever Happy Marriage Bureau and not the marriage of Mr Lonely, under Article 293 CC. Therefore, the contract can remain partially valid with regard to the payment for the introductions service (not necessarily correspondent to the deposit of EUR 7,000 - it can be any other sum mutually agreed). This 'reduction' or 'conversion' of the original legal transaction is only precluded when it is clear that the parties would not have entered into the agreement if it did not include the clause held null (Articles 292 and 293 CC).

VARIATION: Similar to the original scenario, the contracts may be held partially valid, as far as the parties would have entered into them had they known that the condition precedent was null. $\mathrm{Mr}$ and Mrs Settled should thus pay for the services rendered by the agency (not necessarily correspondent to the deposit of EUR 2,000 - it can be any other sum mutually agreed). However, the clause imposing a payment once a marriage occurs should be held null for violating public policy and good morals, so Mr and Mrs Settled can challenge the claim of the agency and refuse to pay a sum expressly dependent of the clients marrying or not.

\section{CASE 7}

\section{Operative Rules}

Miss Money may not use the pre-nuptial agreement to deny alimony to Mr Doe.

VARIATION: Mr Money may not use the pre-nuptial agreement to deny alimony to Miss Cinderella.

\section{Descriptive Formants}

Nuptial agreements are regulated by the civil code under the term of 'convenção antenupcial'. They are considered to be subject to the principles of: ${ }^{45}$

\footnotetext{
${ }^{45}$ Pereira Coelho and Oliveira (n 40) $570 \mathrm{ff}$.
} 
- freedom: the parties are free to determine the content of their nuptial agreement, namely to decide which property regime they wish to choose (either from the ones regulated in the civil code or another one they may wish: Article 1698 CC) $)^{46}$ - such agreements are, however, subject to the good morals and public policy clauses; and,

- immutability: such agreements may not, in principle, be amended throughout the life of the parties.

One of the marital property regimes that spouses can choose from, and which is regulated in Articles $1735 \mathrm{ff} \mathrm{CC}$, is 'separação de bens', literally 'separation of goods'. This regime retains the separation between the spouses' patrimony throughout the marriage, thus resembling the scenario described in this case. The civil code, however, does not seem to allow spouses to deny alimony in neither a 'separation of goods' marital property regime nor in a 'tailored' regime in a nuptial agreement. Indeed, Articles 2008-2009 CC bind ex-spouses to alimony obligations and prohibit individuals from renouncing the corresponding rights (although individuals may choose not to exercise their right, may renounce past alimony, and are not entitled to the same standard of living they enjoyed during married life). In addition, Article 2016 CC entitles exspouses to a right to alimony independently of the type of divorce (amicable or without consent). Articles 2016(3) and 2019 do allow, however, an ex-spouse to deny alimony on grounds of equity or the recipient's immoral conduct, which does not seem to apply to the scenario at hand. Moreover, the ex-spouse does not have the right to demand maintaining the lifestyle enjoyed up until the divorce (Article 2016-A (3)). ${ }^{47}$ Finally, it has been increasingly asserted that the duty to pay alimony is exceptional, transitory and dependent on circumstances, as it should only exist during the period between the end of the matrimony and the (re)start of the professional activity of the ex-spouse receiving alimony, on the basis that ex-spouses should provide for themselves. $^{48}$

\footnotetext{
${ }^{46}$ If spouses do not enter into a nuptial agreement, the suppletive marital property regime applies, which is the community of acquests (communal estate comprising only property acquired after their marriage), as stipulated in Article 1717 CC.

${ }^{47}$ Pereira Coelho and Oliveira (n 40) 774-776.

${ }^{48}$ Diogo Leite de Campos and Mónica Martinez de Campos, Lições de Direito da Família, 3th edition (Coimbra: Almedina, 2016) 357. See, also, Supremo Tribunal de Justiça, Processos n. ${ }^{\circ}$ 320/10.6TBTMR.C1.S1 (23 October 2012); 141/10.6TMSTB.E1.S1 (20 February 2014); Tribunal da Relação de Lisboa (Court of Appeal of Lisbon), Processo n. ${ }^{\circ} 382 / 16.2$ T8SXL.L1-2 (22 March 2018); Tribunal da Relação do Porto (Court of Appeal of Porto), Processos n. ${ }^{\circ}$ 11425/08-3TBVNG.pl (19 September 2011); 224/11.5T6AVR-B.P2 (13 October 2016).
} 
Article 1699 CC limits the freedom to determine the content of nuptial agreements by, among other things, not allowing any change to the parental and marital rights or duties, as these are determined by imperative norms (that is, norms that do not allow for any deviation based on private autonomy). Articles 2008, 2009 and 2016 CC imposing alimony obligations on exspouses seem to be of peremptory nature and part of such 'marital rights or duties' from which spouses may not deviate in their nuptial agreements. One may argue in favour of a reform of these norms due to the need to respect the parties' private autonomy; in other words, if a nuptial agreement excludes the granting of a right to alimony after a divorce, the parties' will so expressed should be respected, as such will does not impact personal values or public interests regarding the organisation of marriage and family. ${ }^{49}$ Still, as the law stands, it seems clear that renouncing the right to alimony in the context of a nuptial agreement is a violation of an imperative norm, and thus null (Articles 294 and 1699 CC).

If one concludes that a particular clause in a nuptial agreement is null, the agreement itself may still be valid, if it is ascertained that the parties would still have entered into the agreement without the clause in question (Article 292 CC).

VARIATION: The same solution as above applies. It may be interesting to note that, even if Miss Cinderella and Mr Money had not married, Miss Cinderella would still be entitled to alimony, as Article $1884 \mathrm{CC}$ establishes that unmarried mothers have the right to claim alimony from the fathers of their children.

\section{CASE 8}

\section{Operative Rules}

The contract is not valid. Clementine has to repay the amount spent by Mr Strict on her trip. VARIATION: It would not make any difference; same solution applies.

\footnotetext{
${ }^{49}$ Argument used with regard to the possibility of changing the property regime, which one can use by analogy in the context of the right to alimony: Pereira Coelho and Oliveira (n 40) $571 \mathrm{ff}$. In harmony with this emphasis on the autonomy of the spouses, Lei n. ${ }^{\circ}$ 48/2018, 14 August 2018, recognised that under Article 1707-A CC spouses may use the nuptial agreement to mutually renounce the status of legal successor ('herdeiro legitimário'), even if this possibility only exists when spouses marry on the basis of 'separation of goods' ('separação de bens', Articles $1735 \mathrm{ff} \mathrm{CC})$.
} 


\section{Descriptive Formants}

Article 398(2) CC determines that:

'The obligation does not need to possess pecuniary value, but it needs to correspond to an interest of the creditor worthy of legal protection.'

This has been interpreted as meaning that interests of ideal or moral order may be the object of legal transactions, but: (i) the creditor's interest in seeing the obligation(s) in question fulfilled must be serious and not a simple whim or fantasy, and (ii) the debtor must have taken on an actual legal obligation and not a mere moral or courtesy commitment. ${ }^{50}$ Whether or not the creditor's interest is 'worthy of legal protection' is something left to the judge's discretion, but should be decided in harmony with the legislature's general guidance. This apparently means that obligations that may be protected by other (moral, religious, etc.) systems may not deserve legal protection (for example, greeting neighbours or attending mass). ${ }^{51}$

Celibacy clauses have been consensually considered null in Portuguese legal studies, for being against public policy, namely with regard to the core of the fundamental right to form a family and marry (Article $36 \mathrm{CRP}$ ). This applies, for example, in the context of employment agreements $^{52}$ and nuptial agreements (for example, prohibition of a second marriage). ${ }^{53}$ The contract in this case is similar to a celibacy clause, to the extent that it has the effect of limiting Clementine's fundamental right to marry, which includes the right to marry whom she chooses and not be constrained to marry anyone in particular. The contract between Mr Strict and Clementine is therefore void for violating public policy and good morals (Article 280(2) CC). ${ }^{54}$ Clementine will need to repay all the money Mr Strict spent on her trip, not because she did not fulfil her obligation under the contract, but because null contracts may not produce any result

\footnotetext{
${ }^{50}$ Almeida Costa (n 6) 626.

51 Ibid 627.

${ }^{52}$ Pereira Coelho and Oliveira (n 40) 130-33; Tavares dos Reis (n 22) 75.

${ }^{53}$ Pereira Coelho and Oliveira (n 40) 576.

${ }^{54}$ This scenario could also be seen as a donation upon condition, regulated by Articles 967 and 2230 CC. In this case, the donation would be valid despite the condition being void, which would mean that Clementine would not need to reimburse Mr Strict. In favour of this approach is the aim of the law to preserve the freedom to marry, as the obligation to repay Mr Strict can be seen as a form of pressure to marry. Against this approach, one could argue that the facts of the case seem to be more appropriately interpreted as a simple contract, not a donation upon condition: indeed, future legal effects (the payment of the trip) do not depend of a future and uncertain event (the marriage), because the payment of the trip occurs before any marriage occurs.
} 
and parties are obliged to return all they have received on account of such contract (Article 289 $\mathrm{CC})$.

VARIATION: The same solution applies. Same-sex partnerships and marriages are both legally recognised in Portuguese law, ${ }^{55}$ and the fundamental right to marry now clearly encompasses the right to marry a person either of the same or opposite sex.

\section{CASE 9}

\section{Operative Rules}

The other brothers can challenge their exclusion.

\section{Descriptive Formants}

According to Article $2026 \mathrm{CC}$, succession is determined by the law, will or contract (the Portuguese terminology for contract of succession being 'pacto sucessório'). Succession contracts are only allowed in the precise terms allowed by the law, otherwise they are held null (Article $2028 \mathrm{CC}$ ). The principle, therefore, is that succession contracts are in principle forbidden for the sake of protecting the freedom of the deceased up to their death, ${ }^{56}$ except where the law (under strict conditions) allows them, such as in the case of nuptial agreements (Articles $1700 \mathrm{ffCC}$ ) and donation whilst alive but only producing effects after the death of the donor (Article 946(2) CC). However, the scenario in question does not seem to constitute a succession contract as understood by Portuguese law, as the individuals affected (the four sons in 2012) will not have entered into such an agreement (in 1930). The agreement in question resembles more a policy set by the 'head of family' at the time with the intention of binding subsequent generations. At any rate, any contract that may somehow limit the freedom of the deceased to change their mind up to their death should be held null, as it is immoral for someone

\footnotetext{
${ }^{55}$ Lei n. $^{\circ}$ 7/2001, 11 May 2001, protecting life partnerships, and Lei n. ${ }^{\circ}$ 9/2010 31 May 2010, allowing civil marriage between persons of the same sex.

${ }^{56}$ Luís A. Carvalho Fernandes, Lições de Direito de Successões, 3rd edition (revised and updated) (Lisboa: Quid Juris, 2008) 558.
} 
to restrict the testator's freedom of testation whilst they are still alive, or to commit to accept or renounce a certain inheritance of someone still alive. ${ }^{57}$

In the context of wills, the law allows conditions to be attached to the wills subject to respect for the law, public policy and good morals (Article $2230 \mathrm{CC}$ ). The law explicitly considers unlawful, amongst others, those conditions restricting one's acceptance of the inheritance to (not) living in a certain place, (not) marrying a certain person, and (not) entering a certain profession (Article 2232 and $2233 \mathrm{CC}$ ), on grounds of significantly restricting the individual freedom of the recipient of the inheritance. ${ }^{58}$ Such conditions are deemed to have not been written (Article 2230(2) CC), which means that the will is still valid and the heir is not affected by the condition, even if the testator had expressed the opposite wish. However, if the clause in question was essentially determined by an 'aim' against the law, good morals or public policy, then the whole will may also be null (Article $2186 \mathrm{CC}$ ), as to punish the real motivation of the deceased. ${ }^{59}$ This set of rules applicable to conditions attached to wills can be applied by analogy to contracts of succession, thereby rendering null any condition relating to one's marriage, namely for violating that individual's right to personal identity, development of personality, marriage and freedom of religion. If the 'aim' of the contract was against good morals and public policy, as it is the case in this scenario, then the whole contract should be held null, and succession should be determined by the general legal regime.

Finally, and most importantly, Portuguese law establishes peremptory norms regarding legal succession. Amongst these, Articles $2156 \mathrm{ff} \mathrm{CC}$ establish that, even in the case of the existence of a will, a certain portion of the inheritance (between half and two thirds thereof, depending on who will inherit) may not be object of the will and is subject to a set of norms called 'sucessão legitimária'. These norms establish that a group of people, including the spouse, ${ }^{60}$ descendants and ascendants, are entitled to this portion of the inheritance except if they are considered 'unworthy' of their legal share of the inheritance (that is, disinherited). This can only occur in the conditions set in the law (Article 2166 CC): if the heir has been convicted for

\footnotetext{
${ }^{57}$ Ibid 559.

${ }^{58}$ Ibid 520; Eduardo dos Santos, Direito de Successões (Lisboa: AAFDL, 2002) 533; Guilherme de Oliveira, Temas de Direito da Família, vol. I, 2nd edition (augmented) (Coimbra: Coimbra Editora, 2001) 164-5; Mota Pinto (n 24) 566-571.

${ }^{59}$ Carvalho Fernandes (n 56) 522; Santos (n 58) 532.

${ }^{60}$ Nonetheless, Article 1707-A CC now recognises spouses the possibility of using the nuptial agreement to mutually renounce the status of legal successor ('herdeiro legitimário'), even if this possibility only exists when spouses marry on the basis of 'separation of goods' ('separação de bens', Articles $1735 \mathrm{ff} \mathrm{CC).}$
} 
an intentional crime against the person, property or honour of the deceased, their spouse, descendant or ascendant, as long as the crime in question is punished by imprisonment for more than six months; if the heir has been convicted of false accusation or testimony against the same group of people; or if the heir refused the alimony due to the deceased or their spouse without a just cause. In the present scenario, that does not seem to have been the case, consequently, all four children are legally entitled to an equal share of two thirds of the inheritance (Article 2159(2) CC), that is, to one sixth of the inheritance. Any attempt to deprive one of the individuals legally entitled to inherit according to the 'sucessão legitimária' rules, will be held null for violating the good morals and public policy clauses. ${ }^{61}$

\section{CASE 10}

\section{Operative Rules}

Mr Broke can challenge Mr Coin's claim.

\section{Descriptive Formants}

As discussed in Case 4 above, one may voluntarily limit their fundamental and personality rights, but such limitations are held to be null when deemed contrary to public policy (Article 81(1) CC). The limitations in question in this case are deeply harmful to Mr Broke's fundamental rights and go beyond his right to renounce his rights. The contract is therefore null and may not produce any result. The parties are obliged to return all they have received on account of such contract (Article $289 \mathrm{CC}$ ), so Mr Broke will need to repay all the capital borrowed from Mr Coin, and possibly some interest as well to avoid a claim of unjust enrichment (Article $473 \mathrm{CC}$ ), although that amount may be smaller than the interest Mr Broke would have to pay under the contract entered into with Mr Coin.

\footnotetext{
${ }^{61}$ Case law has confirmed that the good morals clause applies to such circumstances, although in the particular case the finding was that there had not been any intention to prevent an individual legally entitled to inherit from inheriting: Supremo Tribunal de Justiça, Processo n. ${ }^{\circ}$ 2135/04 (30 November 2010).
} 


\title{
CASE 11
}

\section{Operative Rules}

Ms Moneypenny can challenge the Bank’s claim.

\section{Descriptive Formants}

The rules on usurious legal transactions aim to protect not only the principle of autonomy or a certain notion of morality, but also the principle of equivalence and internal justice in contracts. $^{62}$ The previous Civil Code (1867-1966) defined usury as a contract establishing an interest rate higher than that legally allowed $(8 \%$ or $10 \%$, depending on whether the debt was protected by a real estate collateral). ${ }^{63}$ The current Portuguese Civil Code, however, has opted for a much broader framework, without resorting to precise figures and percentages, which offers decision-makers a wide margin of appreciation. ${ }^{64}$ Article $282 \mathrm{CC}$ determines that:

\begin{abstract}
'A legal transaction is voidable, due to usury, when someone, exploiting someone else's state of necessity, inexperience, thoughtlessness, dependency, mental condition or character weakness, obtains from the latter, for themselves or a third party, the promise or concession of excessive or unjustified benefits. ${ }^{, 65}$
\end{abstract}

The key elements of the concept of usury are, therefore: (i) the position of inferiority of one of the parties (subjective element), (ii) obtaining excessive or unjustified benefits (objective element), and (iii) intention or consciousness of the other party of exploiting such situation of inferiority (subjective element). ${ }^{66}$

The civil code norm establishes a range of situations that may account for the inferiority of one of the parties, but one may invoke other legally relevant circumstances analogous to the ones

\footnotetext{
${ }^{62}$ Adriano Marteleto Godinho, Usura e lesão nos contratos sob a ótica dos Códigos Civis Português e Brasileiro (Lisboa: Universidade de Lisboa / Faculdade de Direito, 2006) 31.

${ }^{63}$ Articles 2 and 3 of Decreto n. ${ }^{\circ} 21.730,14$ October 1932.

${ }^{64}$ Marteleto Godinho (n 62) 34; Jorge Sinde Monteiro and André Dias Pereira, 'Surety Protection in Portugal', in: A. Colombi Ciacchi (ed.), Protection of Non-Professional Sureties in Europe: Formal and Substantive Disparity (Baden-Baden: Nomos, 2007) 231-245 (discussion of usury at $240 \mathrm{ff}$ ).

${ }^{65}$ This wording is the result of the amendment introduced by Decreto-lei n. ${ }^{\circ}$ 262/83, 16 June 1983.

${ }^{66}$ Almeida Costa (n 6) 621; Mota Pinto (n 24) 536-7.
} 
expressly mentioned in the law; that does not mean, however, that the law will protect the mere lack of caution of a contractual party. ${ }^{67}$ As for those circumstances that the law does expressly mention: 'inexperience' may occur both in relation to individuals completely unfamiliar with any type of contract, and to individuals who may have general experience but are not familiar with the type of contract in question; 'state of necessity' should be assessed with regard to the need to enter the contract in question for some financial, moral or any other type of reason, not necessarily with the lack of economic resources; ${ }^{68}$ 'thoughtlessness' consists of entering into an agreement without reflecting appropriately upon all its terms and effects; 'dependency' may be of any order, including economic, emotional, psychological and professional; 'mental condition' refers to weak or lack of mental or emotional control; and 'character weakness' has to do with the immorality or shyness of an individual, despite their mental capacity. ${ }^{69}$ This broad range of grounds has been criticised by several Portuguese authors, in particular 'thoughtlessness', 'mental condition' and 'character weakness', as they may excessively protect the 'weak' party and render the interpretation task of the decision-maker too complicated. ${ }^{70}$

To measure whether the benefit obtained is excessive or unjustified, one should refer to the moment of entering the agreement, and may resort, for example, to expert opinions and comparisons between similar contracts. ${ }^{71}$ Since the legal consequence of usury is that the legal transaction is merely voidable - not void - the party exploited may choose to modify the transaction (provided such modification is equitable) and, should the party affected request that the transaction be voided, the other party is also entitled to request that the transaction be modified instead (Article 283 CC).

Having to prove the intention or consciousness of the other party of exploiting a situation of inferiority may be very complex and limit the possibility of success in a claim. ${ }^{72}$ Usury has

\footnotetext{
${ }^{67}$ Marteleto Godinho (n 62) 37.

${ }^{68}$ For example, signing an offer to sell (forward commitment or 'contrato promessa') for the sake of preventing the repossession of a house and its judicial sale: Tribunal da Relação de Coimbra (Court of Appeal of Coimbra), Processo n. ${ }^{\circ}$ 19/07, 3 November 2009.

${ }^{69}$ Marteleto Godinho (n 62) 38-40.

${ }^{70}$ Ibid 39-41.

${ }^{71}$ Ibid 35-6.

${ }^{72}$ Decreto-lei n. ${ }^{\circ} 262 / 83$, 16 June 1983, changed this norm's wording from 'consciously taking advantage' to 'exploiting'. The reach of this amendment is not consensual, with some authors claiming that 'exploitation' may be objective (that is, even in the absence of knowledge of the other party's situation of inferiority), whilst other authors assert that there is only usury if, besides realising the other party's situation of inferiority, one also intends to exploit such situation. The latter position seems to be favoured by the majority of authors and courts (Supremo
} 
indeed been described as a legal notion of 'fragile capacity of determinability', has been the object of a very limited number of judicial decisions and is rarely considered by courts, even if it remains available as a $\operatorname{cog}$ in the system. ${ }^{73}$ However, one of the few decisions identified supports a generous approach to the application of the legal regime on usurious legal transactions. $^{74}$

The rules on loans on interests constitute a special regime in relation to the rules on usurious contracts (Article 282(2) CC): in relation to loans on interests, Articles 559-A and $1146 \mathrm{CC}$ determine that loans and all related transactions are considered usurious if they entail annual interest rates of $3 \%$ or $5 \%$, beyond the interest rates legally established, depending on whether or not the debt is protected by a real estate collateral. In such cases, the interest rate is considered to be the maximum legally allowed, independently of the will of the parties (Article 1146(3) $\mathrm{CC}$ ). Such reduction of the interest rate does not prevent, however, the application of the more general provision on usurious legal transactions in Article 282 CC (Article 1146(4) CC). Indeed, even if the interest rate remains within the legal limits, the legal transaction may be held usurious on other accounts, as the notion of usury under Article $282 \mathrm{CC}$ is broader than the one considered in Article 1146 CC.

The interest rate charged by the Bond Bank to Ms Moneypenny entails an annual interest rate of $5 \%$, beyond the interest rates legally established, so the interest rate in this contract should become the maximum legally allowed (Article 1146(3) CC). The contract may even be considered voidable, if Ms Moneypenny proves the requirements established for usury (for example, if the bank exploited her state of necessity). In that case, Ms Moneypenny may request either that the contract be voided (Article $287 \mathrm{CC}$ ) or that it be modified as to be rendered equitable (Article $283 \mathrm{CC}$ ).

\footnotetext{
Tribunal de Justiça, Processo n. ${ }^{\circ}$ 06A1988, 12 September 2006). For a discussion of these opinions, see Marteleto Godinho (n 54) 42-44.

${ }^{73}$ Menezes Cordeiro (n 6) 459-60.

${ }^{74}$ Supremo Tribunal de Justiça, Processo n. ${ }^{\circ}$ 06A1988 (12 September 2006), where a party allegedly charged excessive interest, in practice receiving around three times more interest than legally allowed.
} 


\section{CASE 12}

\section{Operative Rules}

Miss Penny can challenge the Bank's claim.

VARIATION: Most likely yes.

\section{Descriptive Formants}

Suretyship agreements are regulated by Articles 627-655 CC in general and classical terms. Suretyship agreements need to contain a minimum range of information, generally including the amount of debt guaranteed, for how long the guarantee will stand, the identification of the debtor and of the creditor, and the range of elements that may burden the position of the guarantor. ${ }^{75}$ Should one or more of these elements be missing, in particular the amount of debt guaranteed, the suretyship agreement in question violates the good morals clause and may be held null. ${ }^{76}$ The legislation on standard contractual terms also establishes a duty to communicate and inform about the terms of the contract (Articles 5 and 6). ${ }^{77}$

Strictly speaking, an individual may act as guarantor even if they do not possess any patrimony, provided the duty of information has been respected and the guarantor expressed their will according to the legal requirements. However, Portuguese scholars have expressed great awareness of the type of scenarios described in this case, by making direct reference to German case law and scholars on this matter: although not making any reference to fundamental rights, the position of spouses and children has been recognised as particularly weak in the light of their limited economic resources and economic and emotional dependency, lack of information provided by banks, and the fact that banks have trivialised suretyship agreements as mere

\footnotetext{
${ }^{75}$ Manuel Januário da Costa Gomes, Assunção fidejussória de divida: Sobre o sentido e o âmbito da vinculação como fiador (Coimbra: Almedina, 2000) $516 \mathrm{ff}$.

${ }^{76}$ Ibid 517; Tribunal da Relação de Lisboa (Court of Appeal of Lisbon), Processo n. ${ }^{\circ}$ 1671/2007 (15 March 2007), and Processo n. ${ }^{\circ}$ 4890/2007 (18 September 2007); Tribunal da Relação do Porto (Court of Appeal of Porto), Processo n. ${ }^{\circ}$ 24453/15.3T8PRT-A.P1 (14 March 2017).

${ }^{77}$ Decreto-Lei n. $^{\circ}$ 446/85, 25 October 1985, as amended successfully on several occasions, generally referred to as LCCG ('Lei das Cláusulas Contratuais Gerais', i.e., 'Contractual Standard Terms Act'). See, for example, Tribunal da Relação de Lisboa (Court of Appeal of Lisbon), Processo n. ${ }^{\circ}$ 5559/2007 (8 November 2016).
} 
formalities. ${ }^{78}$ Even assuming that bank employees do not act with the intention to harm the guarantor, but simply to secure another debtor, the law needs to tackle mass indebtedness by regulating contractual autonomy in the light of good faith and good morals. ${ }^{79}$

Costa Gomes argues that, in the light of the similarity between the Portuguese and the German civil codes and constitutions, the German case law on (immoral) suretyship agreements should inform the solutions adopted by the Portuguese legal system in this regard. ${ }^{80}$ Bearing this in mind, suretyship agreements in Portuguese law should also be regulated to the effect of protecting the truly free exercise of one's private autonomy (including the duty to inform the guarantor), ${ }^{81}$ which may in extreme cases require the correction of agreements characterised by a strong imbalance between the parties and abnormally harmful consequences to the guarantor. Moreover, one's freedom to decide whether to enter into a suretyship agreement or not needs to be particularly well protected in the case of people without patrimony / income and personally or economically connected to or dependent of the debtor, by subjecting such cases to the good faith, good morals and public policy clauses. ${ }^{82}$

According to Costa Gomes, what may distinguish the German and the Portuguese solutions is the fact that under Portuguese law such suretyship agreements need to be assessed not only under the good morals clause (Article 280(2) CC), but also under the norm on usurious legal transactions (Article $282 \mathrm{CC}$ ) ${ }^{83}$ Usury being a particular case of violation of good morals, the same agreement can be considered both usurious and against good morals, in which case the first instance of unlawfulness may be subsumed within the second instance. It is also possible to envisage a suretyship agreement which is not usurious, but against good morals nonetheless. The key aspect here is that if the agreement is only held to be usurious, then it is voidable; if it is held against good morals more generally, then it is void. ${ }^{84}$ In either case, the assessment of the lawfulness of the agreement should refer to the moment when the parties entered into the

\footnotetext{
${ }^{78}$ Sinde Monteiro and Dias Pereira (n 64); Jorge Sinde Monteiro and André Dias Pereira, 'Portugal', in: A. Colombi Ciacchi and S. Weatherill (eds), Regulating Unfair Banking Practices in Europe: The Case of Personal Suretyships (Oxford: Oxford University Press, 2010) 453-467; Costa Gomes (n 75) 541 ff.

${ }^{79}$ Costa Gomes (n 75) 542-3.

${ }^{80}$ Ibid 544.

${ }^{81}$ Ibid $577 \mathrm{ff}$. See also, in relation to omnibus suretyship agreements but applicable to any suretyship agreement, Frederico Faro, Fiança omnibus no âmbito bancário: Validade e exercício da garantia à luz do princípio da boa fé (Coimbra: Coimbra Editora, 2009) $376 \mathrm{ff}$.

${ }^{82}$ Costa Gomes (n 75) 549-50.

${ }^{83}$ Ibid 554-5.

${ }^{84}$ Ibid 554-6.
} 
agreement. In a case such as the one at hand (involving the vulnerability of the guarantor, economic and/or emotional dependency from the debtor, and lack of patrimony/income), Costa Gomes seems to favour the solution of nullity of the suretyship agreement for violation of good morals. ${ }^{85}$

VARIATION: Despite the economic and emotional dependency of the debtor, Ms Hazard arguably has the necessary professional experience and income to offer the guarantee in question. The suretyship agreement should therefore not be considered null for violating good morals or public policy, but it could still be considered voidable if one finds that usury has taken place. Nonetheless, even if Ms Hazard were acting in a state of necessity or another situation of inferiority, it would perhaps be difficult to prove that the bank obtained an excessive or unjustified benefit and that it acted with the intention or consciousness of exploiting Ms Hazard's situation of inferiority.

\footnotetext{
${ }^{85}$ Ibid 558-9.
} 